\title{
PROTOZOAN GENITAL INVASIONS CAUSED BY THE REPRESENTATIVES OF TRICHOMONAS AND GIARDIA
}

DOI: 10.36740/WLek202002133

\author{
Pavlo V. Fedorych', Gennadiy I. Mavrov², Tetiana V. Osinska², Yuliia V. Shcherbakova² \\ 'UKRAINIAN MILITARY MEDICAL ACADEMY, KYIV, UKRAINE \\ ¿STATE ESTABLISHMENT “INSTITUTE OF DERMATOLOGY AND VENEREOLOGY OF THE NATIONAL ACADEMY OF MEDICAL SCIENCES OF UKRAINE", \\ KHARKIV, UKRAINE
}

\begin{abstract}
The aim was to perform systematic review of genitourinary protozoan invasion and analyze their pathogenicity and the ability to influence the genitourinary infections. Materials and methods: For systematic review of papers the EMBASE and PubMed databases were searched. We also reviewed our own pilot studies using real-time polymerase chain reaction (PCR) to determine Trichomonas tenax, Pentatrichomonas hominis and Giardia lamblia.

Conclusions: Trichomonas tenax, Pentatrichomonas hominis, Giardia lamblia can cause genitourinary invasion in addition to Trichomonas vaginalis. Their eradication is obligatory at least for not keeping intact pathogenic microorganisms phagocyted by Trichomonas spp. Defining the protozoan forms is important in preventing of genital infections recurrences and reinfections.
\end{abstract}

KEY WORDS: Trichomonas vaginalis, Trichomonas tenax, Pentatrichomonas hominis, Giardia lamblia

Wiad Lek. 2020;73(2):380-383

\section{INTRODUCTION}

Parasitic invasion is a medical and biological notion that defines the totality of the processes that occur during an infectious process - the interaction of the pathogen and the host organism, when the causative agents are parasites. In epidemiology and parasitology, invasion refers to the fact that parasites have entered the host organism, that is infection, as a rule, with parasitic fungi, protozoa, parasitic worms or diseases caused by parasitic pathogens: fungal invasions, protozoan invasions [1].

It is known that several dozen of the protozoan microorganisms can live in the human body. Morphologically, they can be very similar to Trichomonas vaginalis [2]. For example, a person can be a carrier of three types of Trichomonas: Trichomonas tenax (elongata), Pentatrichomonas hominis (abdominalis), Trichomonas vaginalis [3]. Trichomonas tenax lives in the oral cavity in carious teeth and inflamed gingival pockets. Pentatrichomonas hominis is a commensal of the human large intestine; its presence is known to be determined in the digestive system of all vertebrates $[4,5,6]$. However, until recently Pentatrichomonas hominis has been believed to be able to live in the genitourinary tract [7].

In the process of in-depth study of methods for diagnosing urogenital trichomoniasis (UT), our attention was attracted by identifying a certain number of inconsistencies in identifying this pathogen provided that various diagnostic methods were used simultaneously [8]. So, with the simultaneous use of optical microscopy and PCR in the study of the same biological material in the same patients, the results were discordant significantly. Moreover, contrary to expectations, the technique of optical microscopy was more effective than PCR. Despite the much greater specificity and sensitivity of PCR than optical microscopy, we made an assumption about the possible existence of other protozoa in the human genitourinary system other than Trichomonas vaginalis. A similar assumption was periodically made by specialists from different countries; however, cases of Trichomonas tenax and Pentatrichomonas hominis detection in the human genitourinary system were sporadic, showed no signs of mass character, and were considered, as a rule, the result of contamination during biological material collection [9]. Nevertheless, there are numerous data on the identification of Pentatrichomonas hominis and Trichomonas tenax in various human organs and systems. As for lamblia, the detection of Giardia lamblia in the genitourinary system of STI patients is about $6 \%[10,11,12]$. In the last decade, in the foreign scientific literature, there have been reports of the genitourinary system lesion by Giardia lamblia, in particular, in homosexual men $[13,14,15]$.

Based on the above, at the present stage, there is a need for a more thorough study of representatives of the protozoa type in terms of their ability to colonize the human genitourinary system and the acquisition of pathogenic properties. Over the past few decades, the living conditions of modern people have changed significantly. At the same time, as is known, the pathogenicity of certain microorganisms in the human genitourinary system (for example, mycoplasmas and gardnerellas) has changed [16]. 
It can be assumed that Giardia lamblia is highly prevalent in the genitourinary system of patients who suffer from STIs. We can also assume that Trichomonas (Trichomonas tenax, Pentatrichomonas hominis), which (as thought until recently) are non-pathogenic for the urogenital tract, could also experience a certain pathomorphosis and acquire the ability to colonize the genitourinary system. It is likely that such properties could occur when these pathogens enter the genitourinary system during unprotected oral and anal sex, respectively, which are very common in modern sexual relationships.

\section{THE AIM}

The aim was to perform systematic review of genitourinary protozoan invasions, analyze their pathogenicity and the ability to influence the genitourinary infections.

\section{MATERIALS AND METHODS}

For systematic review of papers the EMBASE and PubMed databases were searched with date ranges between 2004 and 2019. Search words included: genital invasions, Trichomonas vaginalis, Trichomonas tenax, Pentatrichomonas hominis, Giardia lamblia, sexually transmitted infections, and infestations. We also reviewed our own pilot studies using experimental original primers that were designed specifically to determine Trichomonas tenax, Pentatrichomonas hominis and Giardia lamblia using modern modification of the PCR - Real-Time PCR.

\section{REVIEW AND DISCUSSION}

These studies in various groups of patients with STIs showed a wide prevalence of protozoan invasions of the genitourinary system caused by Trichomonas tenax, Pentatrichomonas hominis and Giardia lamblia [17]. Thus, for example, protozoan invasions in the genitourinary system were found in $71(44.9 \pm 3.4 \%)$ of 158 examined patients with an STI chronicity. The study group consisted of 45 men $(63.4 \%)$ and 26 women (36.6\%). Trichomonas tenax was diagnosed in 13 patients (18.3\%): 10 men (22.2\% of all men) and 3 women (11.5\% of all women). Pentatrichomonas hominis was diagnosed in 48 patients (67.6\%): 29 men ( $64.4 \%$ of all men) and 19 women (73.1 \% of all women). Trichomonas vaginalis - in 1 patient, female (3.8\%). Giardia lamblia was diagnosed in 9 patients (12.7\%): 6 men $(13.3 \%)$ and 3 women $(11.5 \%)$. There were not significant gender differences in the frequency of protozoan invasions of the genitourinary system. The fact that each patient of the experimental group has just a chronic inflammatory process in the genitourinary system allows us to suggest that these microorganisms are potential factors for the occurrence and / or course of urinary infections. It was found that the level of diagnosis of Trichomonas vaginalis in patients with urogenital infections was only about $4 \%$. In addition, it was proved that during the detection of Trichomonas using the method of sowing on the appropri- ate nutrient medium, Trichomonas tenax is often perceived as Trichomonas vaginalis or Pentatrichomonas hominis [18].

Therefore, the possibility of stay in the urinary system three different types of Trichomonas (Trichomonas vaginalis, Trichomonas tenax, Pentatrichomonas hominis) and Giardia lamblia has been established. Answering the question "why the protozoa should be eradicated from genitourinary system?", first of all, the direct damaging effects of Trichomonas vaginalis and Giardia lamblia should be noted [19]. It should be noted separately that the pathogenicity of Trichomonas vaginalis to humans is not limited to inflammation. It has various manifestations, in particular, the role of this pathogen in the formation of pathogenic microbiocenoses, including bacterial vaginosis in women, decreased immunity $[20,21,22]$. In these circumstance the development of hyperplastic processes in the organs of the human genitourinary system, and perinatal pathology may not be excluded [23, 24]. Trichomonas vaginalis can live not only in genitourinary organs but even in the bloodstream, where they penetrate through the intercellular space and lymphatic pathways using the hyaluronidase enzyme [25]. Observations of other extragenital lesions caused by Trichomonas, in particular, of the tonsils, skin and rectum, were also described [19].

Nowadays, Trichomoniasis is considered a mixed protozoan and bacterial infection [20]. When examining patients, it is necessary to take into account that all Trichomonads have phagocytic properties, often with incomplete digestion (incomplete phagocytosis). In the case of incomplete phagocytosis of cocci, diplococci, chlamydia, bacillary forms, viruses appearing at the death of Trichomonas, and are able to support the inflammatory process in the urinary tract, is often perceived as untreated Trichomoniasis or post-trichomonous lesions, creates certain difficulties in prescribing etiotropic treatment $[25,26]$. Therefore, information about such a pathogenetic link helps to properly plan clinical, diagnostic, and preventive measures.

A local study of the incidence of STIs in Ukraine showed that in $64.29 \%$ of patients with UT, Trichomonas vaginalis was found in pathological associations with other sexually transmitted pathogens. The most clinically significant for the genitourinary system of patients are the pathological microbial associations of Trichomonas vaginalis with Human papillomavirus (14.28\%), as well as simultaneously with Chlamydia trachomatis and Mycoplasma hominis (14.28 \%). Moreover, entering into the composition of various microbial associations, Human papillomavirus, Ureaplasma urealyticum, and Chlamydia trachomatis were each defined in 7 (25\%), and Mycoplasma hominis in 10 (35.7\%) patients with UT. Therefore, research on these microorganisms in our region today is most appropriate when conducting diagnostic examinations of patients with UT [26]. There is evidence of the occurrence of pathological microbial associations (MA), which include Trichomonas vaginalis and microflora, which is associated with bacterial vaginosis (BV). MAs are interacting microbial communities. MA may include bacteria, yeast, fungi, and other microorganisms. They are based on symbiotic or metabiotic relationships. Certain types of microorganisms that make up MA are usually resistant to 
waste products of other species and use these products as sources of their existence [3]. Our researches have shown that microorganisms associated with BV are often found in the genitourinary system of patients with Trichomonas tenax and Pentatrichomonas hominis, as well as Giardia lamblia. Moreover, the group of Gardnerella vaginalis / Prevotella bivia / Porphyromonas spp. microorganisms is determined in more than $60 \%$ of relevant patients with Trichomonas tenax. Enterobacteriaceae is diagnosed in almost 11-23\% of patients. The group of Mobiluncus spp. / Corynebacterium spp. microorganisms was diagnosed in $23-33 \%$. Candida spp. is diagnosed more often, in almost $70 \%$ of patients with these pathogens. Eubacterium spp. was found in over $54 \%$ of patients. As for conditionally pathogenic genital mycoplasmas (Ureaplasma (urealyticum + parvum)), they are more often associated with the simplest causative agents of Giardiasis - Giardia lamblia - in almost $45 \%$ of cases [27].

From the practical point of view, for the treatment of combined lesions of the genitourinary system caused by various types of trichomonads and microorganisms associated with $\mathrm{BV}$, for patients with an STI chronicity, as etiotropic therapy means, it is advisable to use sequentially secnidazole $2,0 \mathrm{~g}$ once a day for 5 days and a preparation containing $0.5 \mathrm{~g}$ of ornidazole and $0.5 \mathrm{~g}$ of ciprofloxacin, 1 tablet 3 times a day for weight over $70 \mathrm{~kg}$ and 2 times a day for weight less than $70 \mathrm{~kg}$ for 10 days [28]. In addition, during the eradication of protozoan pathogens, it is desirable to take into account the state of the immune system of the respective patients [22]. Thus, when treating protozoan invasions against the background of primary immunodeficiency in order to correct it, it is advisable to use the drug called "Propes", which is a derivative of the defensin group [29].

\section{CONCLUSIONS}

Trichomonas tenax, Pentatrichomonas hominis, Giardia lamblia can cause genitourinary invasion in addition to Trichomonas vaginalis. Their eradication is obligatory at least for not keeping intact pathogenic microorganisms phagocyted by Trichomonas spp. Defining the protozoan forms is important in preventing of genital infections recurrences and reinfections.

\section{REFERENCES}

1. Graves KJ, Ghosh AP, Kissinger PJ et al. Trichomonas vaginalis virus: a review of the literature. Int J STD AIDS. 2019: 956462418809767. doi: $10.1177 / 0956462418809767$.

2. Kamaruddin M, Tokoro M, Rahman MM et al. Molecular characterization of various trichomonad species isolated from humans and related mammals in Indonesia. Korean J Parasitol. 2014;52(5):471-8. doi: 10.3347/kjp.2014.52.5.471.

3. Bykov A.S. Atlas po meditsinskoy mikrobiologii, virusologii i immunologii. - 2-e izd. [Atlas of medical microbiology, virology and immunology. - 2nd ed.] In: Vorobev A.A., Zverev V.V. et al. Moscow: Medical Information Agency LLC; 2008, p. 753-756. (In Russian).

4. Benabdelkader S, Andreani J, Gillet A et al. Specific clones of Trichomonas tenax are associated with periodontitis. PLOS One. 2019;14(3):e0213338. doi: 10.1371/journal.
5. Neymark SL, Neymark OS. Diskussionnyye problemy diagnostiki i lecheniya trikhomonadnoy infektsii [Debatable problems of diagnosis and treatment of trichomonas infection]. Collection of scientific papers of the Association of Obstetricians and Gynecologists of Ukraine. 2014;12:236-238. (In Russian).

6. Kim Yun-Ah, Kim Hye-Youn, Cho Shin-Hyeong et al. PCR Detection and Molecular Characterization of Pentatrichomonas hominis from Feces of Dogs with Diarrhea in the Republic of Korea. Korean J Parasitol. 2010; 48(1):9-13.doi: 10.3347/kjp.2010.48.

7. Li W, Li W, Gong P et al. Molecular and morphologic identification of Pentatrichomonas hominis in swine. Vet Parasitol. 2014; 202(34):241-247.

8. Fedorych P.V., Zelenyi S.B., Zaitseva L.S. ta insh. Vyznachennia deiakykh naiprostishykh (Trichomonas tenax, Trichomonas hominis, Giardia lamblia, Entamoeba histolytica, Entamoeba gingivalis) u patsiientiv, khvorykh na urohenitalni infektsii metodom PLR v realnomu chasi [Identification of some protozoa (Trichomonas tenax, Trichomonas hominis, Giardia lamblia, Entamoeba histolytica, Entamoeba gingivalis) in patients with urogenital infections by real-time PCR]. Ukrainian Journal of Dermatology, Venereology, Cosmetology. 2012;4(47):5-10. (In Ukrainian).

9. Duboucher C, Caby S, Chabe M et al. Human pulmonary trichomonoses. Presse Med. 2007;36:835-839.

10. Brosh-Nissimov T, Hindiyeh M, Azar R et al. A false-positive Trichomonas vaginalis result due to Trichomonas tenax presence in clinical specimens may reveal a possible T. tenax urogenital infection. Clin Microbiol Infect. 2019;25(1):123-124.

11. Meloni D, Mantini C, Goustille J et al. Molecular identification of Pentatrichomonas hominis in two patients with gastrointestinal symptoms. J. Clin. Pathol. 2011; 64:933-935.

12. Afzan MY, Sivanandam S, Suresh K. Modified Field stain - rapid viability test for Trichomonas vaginalis. J. Appl. Microbiol. 2012;112(1):132-137.

13. Mallat H, Podglajen I, Lavarde V et al. Molecular Characterization of Trichomonas tenax Causing Pulmonary Infection. J. Clin. Microbiol. 2004; 42(8):3886-3887.

14. Workowski KA, Bolan GA. Centers for Disease Control and Prevention. Sexually transmitted diseases treatment guidelines. MMWR 2015;64(RR-03):1-137.

15. Di Benedetto MA, Di Piazza F, Amodio E et al. Prevalence of sexually transmitted infections and enteric protozoa among homosexual men in western Sicily (south Italy). J Prev Med Hyg. 2012;53:181-185.

16. Gbinigie OA, Ordóñez-Mena, JM Fanshawe TR et al. Diagnostic value of symptoms and signs for identifying urinary tract infection in older adult outpatients: Systematic review and meta-analysis. Journal of Infection. 2018;77(5):379-390.

17. Fedorych PV, Mavrov GI. The role of protozoal infestations in chronic inflammation exacerbations in patients with genitourinary pathology, EUREKA: Health Sciences. 2018;5:28-33.

18. Fedorych P.V., Zelenyi S.B., Sadovska 0.A. Porivniannia efektyvnosti diahnostyky trykhomoniazu za kulturalnym metodom ta metodom polimeraznoi lantsiuhovoi reaktsii z vykorystanniam praimeriv dlia vyiavlennia Trichomonas vaginalis, Trichomonas tenax ta Pentatrichomonas hominis [Comparison of the effectiveness of the diagnosis of trichomoniasis by the culture method and the method of polymerase chain reaction using primers to detect Trichomonas vaginalis, Trichomonas tenax, and Pentatrichomonas hominis]. Ukrainian Journal of Dermatology, Venereology, Cosmetology. 2017;1(64):65-69. (In Ukrainian). 
19. Mavrov II. Statevi khvoroby [Sexually transmitted diseases]: Translation from Russian. Ternopil: TSMU, 2005.p.523 - 533 (In Ukrainian).

20. Asmah RH, Blankson HNA, Seanefu KA, et al. Trichomoniasis and associated co-infections of the genital tract among pregnant women presenting at two hospitals in Ghana. BMC Womens Health. 2017;17(1):130. doi:10.1186/s12905-017-0489-5.

21. Koblosh N.D. Stan mikroekolohii statevykh shliakhiv u zhinok z patolohiieiu shyiky matky [The state of the microecology of the genital tract in women with cervical pathology]. Woman's health. 2014;3(89):149-152 (In Ukrainian).

22. Fichorova RN, Yamamoto HS, Fashemi T et al. Trichomonas vaginalis Lipophosphoglycan Exploits Binding to Galectin-1 and -3 to Modulate Epithelial Immunity. J Biol Chem. 2016;291(2):998-1013. doi: 10.1074/ jbc.M115.651497

23. Hui BB, Reulein CP, Guy RJ et al. Impact of replacing cytology with human papillomavirus testing for cervical cancer screening on the prevalence of Trichomonas vaginalis: a modelling study. Sex Transm Infect. 2018;94:216-221. doi:10.1136/sextrans-2017-053294.

24. Bondarenko H.M., Mavrov H.I., Osinska T.V. ta in. Perynatalna invaziia Trichomonas vaginalis, yak problema reproduktyvnoi medytsyny [Perinatal invasion of Trichomonas vaginalis as a problem of reproductive medicine]. Journal of the National Academy of Medical Sciences of Ukraine. 2016;22(3-4):368-376 (In Ukrainian).

25. Riestra AM, Valderrama JA, Patras KA et al. Trichomonas vaginalis induces NLRP3 inflammasome activation and pyroptotic cell death in human macrophages. J Innate Immun. 2019; 11(1): 86-98. doi: $10.1159 / 000493585$.

26. Fedorych PV, Mavrov GI. Incidence of Sexually Transmitted Infections: Local Study in Ukraine. World Science. 2018; 8(36): I.2. doi: 10.31435/ rsglobal_ws/30082018/6059.

27. Fedorych P.V., Mavrov H.I. Doslidzhennia skladu mikrobnykh asotsiatsii zbudnykiv protozoinykh invazii z mikrofloroiu, shcho asotsiiovana z bakterialnym vahinozom u khvorykh na khronichni infektsii sechostatevoi systemy [Study of the composition of microbial associations of pathogens of protozoan invasions with microflora associated with bacterial vaginosis in patients with chronic infections of the genitourinary system. Dermatovenereology. Cosmetology. Sexopathology]. 2018;3-4:18-24. (In Ukrainian).

28. Fedorych P.V. Protozoini invazii sechostatevoi systemy u poiednanni zi zbudnykamy bakterialnoho vahinozu u zhinok fertylnoho viku ta yikh statevykh partneriv [Protozoan invasions of the urogenital system in combination with pathogens of bacterial vaginosis in women of fertile age and their sexual partners]. Woman's health. 2018;7(133):11-16 (In Ukrainian).
29. Fedorych P.V. Novi pidkhody shchodo korektsii imunnoi nedostatnosti v likuvanni khvorykh z trykhomonadnoiu invaziieiu sechostatevoi systemy [New approaches to the correction of immune deficiency in the treatment of patients with trichomonas invasion of the urogenital system]. Dermatovenereology. Cosmetology. Sexopathology. 2018;34:132-146 (In Ukrainian).

Academic research work topic $00116 U 003595$ State Establishment "Institute of Dermatology and Venereology of the National Academy of Medical Sciences of Ukraine" "To optimize the system for laboratory diagnosis of syphilis and trichomoniasis for different levels of medical care to the population in conditions of social instability and emergency situations", in the framework of state funding.

\section{ORCID and contributionship:}

Pavlo V. Fedorych - 0000-0001-8273-0821 A, B, D, F

Gennadiy I. Mavrov - 0000-0002-3645-2792 A, C, F, E, F

Tetiana V. Osinska - 0000-0002-2683-4957 B, C, D

Yuliia V. Shcherbakova - 0000-0002-3682-7451 B, E, F

\section{Conflicts of interest:}

Authors declare no conflict of interest.

\section{CORRESPONDING AUTHOR Pavlo V. Fedorych \\ Ukrainian Military Medical Academy \\ 45/1 General Almazov str., 01015, Kyiv, Ukraine \\ tel: +380672204552 \\ e-mail:pvf9@meta.ua}

Received: 09.05.2019

Accepted: 16.12 .2019

\footnotetext{
A - Work concept and design, B - Data collection and analysis, C - Responsibility for statistical analysis,
} $\mathbf{D}$-Writing the article, $\mathbf{E}$-Critical review, $\mathbf{F}$ - Final approval of the article 